\title{
REGRESSION MODELING OF THE STRENGTH PROPERTIES OF CONCRETE REINFORCED WITH POLYPROPYLENE FIBER AND ALKALI RESISTANT GLASS FIBRE
}

\author{
A. W. Otunyo ${ }^{1, *}$ and A. J. Odebiyi ${ }^{2}$ \\ 1, 2, Dept. Of Civil EngineERInG, Rivers State University NKPOLU, Port Harcourt, Rivers State, NigERIA. \\ Email addresses: ${ }^{1}$ umutuigili@yahoo.com, ${ }^{2}$ odebyi@gmail.com.
}

\begin{abstract}
This paper presents the result of the regression modeling of the strength properties of hybrid fiber reinforced concrete made with polypropylene fiber (PPF) and alkali resistant glass fibre (ARGF). The fibres were added to grade 25 concrete at different proportion of $0.5 \%, 1.0 \%, 1.5 \%$ and $2.0 \%$ of volume of concrete. A total of sixty three cubes samples were tested for compressive strength, twenty four cylindrical samples for split tensile strength and twenty four beam samples for flexural strength. Maximum compressive strength was attained at $1.5 \%$ fibre volume with hybrid fibre ratio of $80 \%$ ARGF and $20 \%$ PPF, maximum split tensile strength was attained at $1.0 \%$ fibre volume with hybrid fibre ratio of $80 \%$ ARGF and $20 \%$ PPF. The beam samples attained its maximum flexural strength at 1.0\% fibre volume with hybrid fibre ratio of $60 \%$ ARGF and $40 \%$ PPF. Empirical expressions were established by using multiple regression analysis to predict the compressive, split tensile and flexural strengths of the hybrid fibre reinforced concrete made with PPF and ARGF. The predicted values compared favourably with the experimental results from all specimens.
\end{abstract}

Key words: alkali resistant glass fibre, compressive strength, flexural strength, hybrid fibre concrete, polypropylene fibre, regression modeling. reinforced concrete, split tensile strength.

\section{INTRODUCTION}

Fibre reinforced concrete is defined as a concrete made of hydraulic cements, fine or fine and coarse aggregates and discontinuous discrete fibres [1-3]. Fibre reinforced concrete is relatively a new construction material developed through extensive research and developmental work during the last three decades. It has already found a wide range of practical applications and proved to be a reliable construction material having superior performance characteristics compared to conventional concrete. Addition of fibres in concrete improved several properties like compressive and tensile strengths, cracking resistance, ductility, durability, flexural strength, impact and wear resistance, toughness, post cracking behaviour of concrete and fatigue resistance [4-6]. The most important contribution from the fibres is the ability to delay crack propagation in the hardened concrete. The internal stresses in the hardened concrete cause the formation of micro cracks, continuous steel reinforcing element cannot stop the development of micro cracks in concrete. Fibres are discontinuous and randomly distributed in the matrix in both tensile and compressive zones of a structural element. Fibres add to the stiffness and crack control performance by transferring the stress within the concrete microstructure and prevent the propagation and growth of the cracks [7]. As a result of fibre characteristic, the flexural strength and resistance under impact and fatigue loading properties can be improved. It has also been observed that addition of fibre to concrete can reduce its brittle nature and alter the mode of failure of the concrete structure [8].

A fibre is a small discrete reinforcing material produced from various materials like steel, plastic, glass, carbon and natural materials in various shapes and sizes [1-3]. The combination of two or more types of fibres in the same concrete mixture can produce a composite with better engineering properties than that containing single fibre. Different types of fibres can be properly combined to produce hybrid fibre reinforced concrete [9].

The mechanical properties of polypropylene fibre reinforced concrete for M25 and M30 mixes was 
investigated by [10]. They observed that with the addition of fibre in the M25 concrete mix, the compressive strength of concrete cylinder increased by $3.23 \%$ at $0.5 \%$ fibre content, $12.15 \%$ at $1.0 \%$ fibre content, $10.48 \%$ at $1.5 \%$ fibre content, $7.57 \%$ at $2.0 \%$ fibre content, $2.98 \%$ at $2.5 \%$ fibre content and $1.53 \%$ at $3.0 \%$ fibre content. The optimum amount of fibre content was $1.0 \%$ giving compressive strength of $31.56 \mathrm{MPa}$ with $12.15 \%$ increase form control specimen. The minimum compressive strength was $28.57 \mathrm{MPa}$ with a $1.52 \%$ increase from the control specimen.

The effect of polypropylene fibres on the strength properties of fly ash based concrete was studied by [11]. Fibre volume fraction of $0.15 \%, 0.2 \%, 0.25 \%$ and $0.3 \%$ was used in fly ash concrete with CLASS C fly ash of specific gravity of 1.96 obtained from NLC. Fly ash content was varied as $30 \%, 40 \%$ and $50 \%$, while the coarse aggregate used was $12 \mathrm{~mm}(40 \%)$, and $20 \mathrm{~mm}$ (60\%) with specific gravity of 2.7 . The compressive strength of concrete mixes made with and without fly ash and polypropylene fiber was determined at 28days as well as 56days. They concluded that the compressive strength of concrete increases gradually by the addition of polypropylene fibre from $0.15 \%$ to $0.3 \%$.

Investigation of glass fibre concrete using M20 grade concrete and glass fibre was carried out by [12]. The glass fibres were added at $0.5 \%, 1.0 \%, 2.0 \%$ and $3.0 \%$. The result of the compressive strength of concrete for 28 days was $27,06 \mathrm{~N} / \mathrm{mm}^{2}, 28.46 \mathrm{~N} / \mathrm{mm}^{2}, 26.88 \mathrm{~N} / \mathrm{mm}^{2}$ and $26.108 \mathrm{~N} / \mathrm{mm}^{2}$ for fibre content of $0.5 \%, 1.0 \%$, $2.0 \%$ and $3.0 \%$ respectively. The percentage increment compared to the normal concrete (without fibre) was $35.3 \%, 42.3 \%, 34.9 \%$ and $30.54 \%$ for the respective fibre content. The flexural strength of $0.5 \%, 1.0 \%, 2.0 \%$ and $3.0 \%$ fibre content at 28 days were observed to be $2.45 \mathrm{~N} / \mathrm{mm}^{2}, 2.94 \mathrm{~N} / \mathrm{mm}^{2}, 2.60 \mathrm{~N} / \mathrm{mm}^{2}$ and $2.45 \mathrm{~N} / \mathrm{mm}^{2}$ respectively. The highest strength was observed at fiber content of $1.0 \%$ for both flexural strength and compressive strength. The split tensile strength was equally observed to be high at $1.0 \%$ having $2.83 \mathrm{~N} / \mathrm{mm}^{2}$ for 7 days and $3.9 \mathrm{~N} / \mathrm{mm}^{2}$ for 28 days.

\section{MATERIALS AND METHOD}

\subsection{Materials}

\subsubsection{Cement}

The cement used for this study is Portland Lime Cement (PLC) produced by Dangote cement factory and conforming to [13]. The manufacturer specification of the cement is "Dangote 3x cement, grade 42.5N"

\subsubsection{Fine Aggregate}

The fine aggregate used for this study was river sand with specific gravity of 2.63 and fines modulus of 3.3, passing through BS $4.75 \mathrm{~mm}$ sieve and conforming to zone 2 as per BS Aggregate [14].

The sand which was obtained from Imo River near Port Harcourt was properly air dried and free from deleterious minerals like clay, silt constituent and chloride contaminants.

\subsubsection{Coarse Aggregate}

The coarse aggregates used was crushed granite with specific gravity of $2.71,52 \%$ of the aggregate was retained on BS13.2mm sieve and conforming to zone 3 as per BS Aggregate [15].

The material was properly dried and free from deleterious materials like clay, silt content and chloride contaminants. The coarse aggregate was obtained from a quarry in Akampa cross river state Nigeria.

\subsubsection{Water}

Clean potable water which satisfied drinking standard and conforming to [16] was used for mixing and curing of concrete samples. It was obtained from the Civil Engineering Laboratory of the Rivers State University, Nkpolu Port Harcourt

\subsubsection{Polypropylene Fibre}

The PPF used in this research work was obtained from Purechem Manufacturing Company in Lagos Nigeria. The properties of the fibre as obtained from the manufacturer is as indicated in Table 1, while Figure 1 is a photograph of the PPF.

Table 1: Fibres properties as specified by the manufacturer

\begin{tabular}{lll}
\hline Type of fibre & Alkali resistant glass fibre & Polypropylene fibre \\
\hline Fiber diameter & 18 microns & $30 \mathrm{Microns}$ \\
Zirconia content & $19 \%$ minimum & Nill \\
Chopped length & $19 \mathrm{~mm}$ & $12 \mathrm{~mm}$ \\
Tensile strength & $1300 \mathrm{MPa}$ & $350 \mathrm{MPa}$ \\
Specific Gravity & $2723.4 \mathrm{Kg} / \mathrm{m}^{3}$ & $0.91 \mathrm{~g} / \mathrm{cm}^{3}$ \\
young modulus & $77.30 \mathrm{Gpa}$ & $5500-7000 \mathrm{MPa}$ \\
Density & $380 \mathrm{Kg} / \mathrm{m}^{3}$ & $215 \mathrm{Kg} / \mathrm{m}^{3}$ \\
Aspect ratio & 1055 & 400 \\
Strain & More than $1.5 \%$ & \\
\hline
\end{tabular}




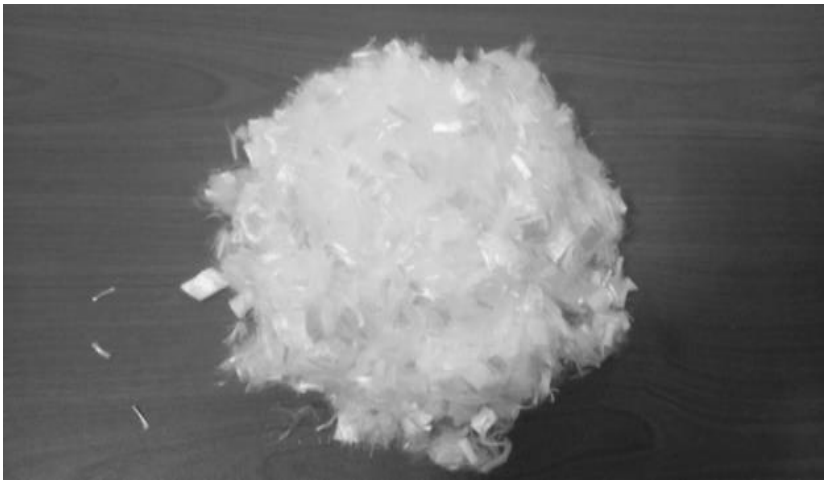

Figure 1: Polypropylene fibre

\subsubsection{Alkali Resistant Glass Fibre}

The alkali resistant glass fibre used for this research work is ACS19PH901X, produced by Nippon Electrical Company Limited in collaboration with Kanebo Limited. The mechanical and physical properties of the fibre is as shown in Table 1, while Figure. 2 is a photograph of the ARGF.

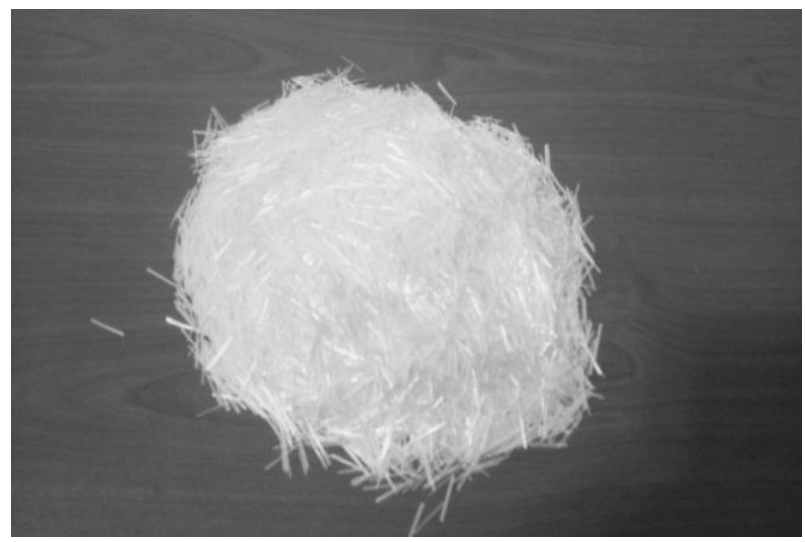

Figure 2: Alkali resistant glass fibre

\subsection{METHOD}

\subsubsection{Concrete Batching and Production of Hfrc}

Concrete batching was done by adopting a ix ratio of 1:1.6:2.7 by weight of cement, sand and granite. It was designed to give a compressive strength of $25 \mathrm{MPa}$ at twenty-eight days and slump value of about $100 \mathrm{~mm}$. Concrete mixing was done by the use of a mechanical concrete mixer in the laboratory. The cement and the fine aggregate (sand) were first placed in the concrete mixer and allowed to rotate for about two minutes, followed by the addition of fibres and one third by weight of water. The fibres were added by percentage volume of concrete in different proportion. Care was taken to avoid balling during the addition of fibre into the mix. The mixture was allowed to rotate in the mixer for two minutes before the addition of coarse aggregate and water. The mixture was allowed for another three minutes for proper mixing while care was taken to

avoid bleeding of concrete. Slump test was conducted at every mix and the slump value recorded. The concrete was placed in concrete moulds which were coated with lubricating oil and compacted with a table vibrator. The concrete samples were allowed in the moulds for twenty four hours after which they were removed from the moulds and placed in a curing tank for twenty eight days.

\subsubsection{Compressive Strength Test}

Concrete cubes were tested for compressive strength in accordance with [17] after 28 days of curing. Sixtythree numbers of $150 \times 150 \times 150 \mathrm{~mm}$ concrete cubes containing hybrid fibre in varying proportion per volume of concrete were tested and the result obtained for each cube recorded. The Automatic Universal Testing Machine was used to carry out the test.

\subsubsection{Splitting Tensile Strength Test}

The test was conducted as specified in [18]. Cylindrical concrete specimen of size $150 \mathrm{~mm}$ diameter x $300 \mathrm{~mm}$ length was cast and cured in water for 28 days. The Automatic Universal Testing Machine was used to carry out the test.

\subsubsection{Flexural Strength Test}

The flexural strength test was performed in accordance to [19]. Twenty-four numbers of $100 \times 100 \times 500 \mathrm{~mm}$ beams were tested and result obtained for each beam recorded. The Hydraulic Jack of 1000 bar was used to carry out the Flexural Strength Test.

\section{RESULTS AND DISCUSSION}

\subsection{Compressive Strength Test Result}

Results obtained from compressive strength test are presented in tabular and chart forms. Table 2 and figure 3 show details of result obtained during the experimental test. Figure 4 shows the compressive strength increment against the fibre volume content.

The addition of fibres to concrete shows significant improvement in compressive strength. The compressive test result shows that at $0.5 \%$ fiber volume, the result obtained for glass and polypropylene fibre reinforced concrete specimen H0.5POG100 and H0.5P100G0 was $37.12 \mathrm{~N} / \mathrm{mm}^{2}$ and $39.63 \mathrm{~N} / \mathrm{mm}^{2}$ respectively showing an increment of $11.71 \%$ and $19.26 \%$ respectively in compressive strength when compared with the control specimen (HOP0G0). Fibre up to a certain percentage reduces crack propagation and brittleness of concrete. [20]. 
Table 2: Compressive strength test experimental result

\begin{tabular}{|c|c|c|c|c|c|c|c|c|c|}
\hline \multirow[b]{2}{*}{$\begin{array}{c}S / N \\
0 .\end{array}$} & \multirow[b]{2}{*}{ Specimen Id } & \multirow[b]{2}{*}{$\begin{array}{c}\text { Volume of } \\
\text { HRF }\end{array}$} & \multicolumn{2}{|c|}{ Volume of individual fiber } & \multicolumn{4}{|c|}{ Compressive strength $\left(\mathrm{N} / \mathrm{mm}^{2}\right)$} & \multirow[b]{2}{*}{$\begin{array}{c}\% \text { Increase in } \\
\text { strength } \\
(\%)\end{array}$} \\
\hline & & & $\begin{array}{l}\text { PPF } \\
(\%)\end{array}$ & $\begin{array}{l}\text { ARGF } \\
(\%)\end{array}$ & $\begin{array}{c}\text { Sample } \\
1\end{array}$ & $\begin{array}{l}\text { Sampl } \\
\text { e } \quad 2\end{array}$ & $\begin{array}{l}\text { Sampl } \\
\text { e } 3\end{array}$ & $\begin{array}{c}\text { Averag } \\
\mathrm{e}\end{array}$ & \\
\hline 1 & $\mathrm{HO}-\mathrm{POGO}$ & 0 & 0 & 0 & 31.19 & 33.8 & 34.7 & 33.23 & Control \\
\hline 2 & $\begin{array}{c}\text { H0.5 - } \\
\text { P0G100 }\end{array}$ & 0.5 & 0 & 100 & 36.32 & 36.1 & 38.95 & 37.12 & 11.71 \\
\hline 3 & $\begin{array}{l}\text { H0.5 - } \\
\text { P100G0 }\end{array}$ & 0.5 & 100 & 0 & 40.08 & 39.96 & 38.85 & 39.63 & 19.26 \\
\hline 4 & $\begin{array}{l}\text { H0.5 - } \\
\text { P2OG80 }\end{array}$ & 0.5 & 20 & 80 & 40.04 & 39.9 & 40.46 & 40.13 & 20.76 \\
\hline 5 & $\begin{array}{l}\mathrm{H} 0.5- \\
\text { P40G60 }\end{array}$ & 0.5 & 40 & 60 & 37.95 & 38.29 & 38.46 & 38.23 & 15.05 \\
\hline 6 & $\begin{array}{l}\text { H0.5 - } \\
\text { P50G50 }\end{array}$ & 0.5 & 50 & 50 & 36.55 & 37.35 & 37.76 & 37.22 & 12.01 \\
\hline 7 & $\begin{array}{l}\text { H1.0 - } \\
\text { P0G100 }\end{array}$ & 1.0 & 0 & 100 & 40.33 & 39.32 & 39.57 & 39.74 & 19.59 \\
\hline 8 & $\begin{array}{l}\mathrm{H} 1.0- \\
\mathrm{P} 100 \mathrm{G} 0\end{array}$ & 1.0 & 100 & 0 & 44.25 & 40.77 & 41.88 & 42.3 & 27.29 \\
\hline 9 & $\begin{array}{l}\mathrm{H} 1.0- \\
\text { P20G80 }\end{array}$ & 1.0 & 20 & 80 & 39.43 & 35.63 & 38.37 & 37.81 & 13.78 \\
\hline 10 & $\begin{array}{l}\mathrm{H} 1.0- \\
\text { P40G60 }\end{array}$ & 1.0 & 40 & 60 & 36.8 & 38.08 & 37.63 & 37.5 & 12.85 \\
\hline 11 & $\begin{array}{l}\text { H1.0 - } \\
\text { P50G50 }\end{array}$ & 1.0 & 50 & 50 & 36.03 & 33.81 & 33.33 & 34.38 & 3.46 \\
\hline 12 & $\begin{array}{l}\text { H1.5 - } \\
\text { P0G100 }\end{array}$ & 1.5 & 0 & 100 & 41.39 & 38.16 & 40.8 & 40.12 & 20.73 \\
\hline 13 & $\begin{array}{l}\mathrm{H} 1.5- \\
\mathrm{P} 100 \mathrm{G} 0\end{array}$ & 1.5 & 100 & 0 & 35.2 & 31.28 & 31.88 & 32.79 & -1.32 \\
\hline 14 & $\begin{array}{l}\mathrm{H} 1.5- \\
\text { P20G80 }\end{array}$ & 1.5 & 20 & 80 & 43.43 & 41.97 & 42.7 & 42.7 & 28.50 \\
\hline 15 & $\begin{array}{l}\mathrm{H} 1.5- \\
\text { P40G60 }\end{array}$ & 1.5 & 40 & 60 & 36.81 & 39.52 & 38.33 & 38.22 & 15.02 \\
\hline 16 & $\begin{array}{l}\mathrm{H} 1.5- \\
\text { P50G50 }\end{array}$ & 1.5 & 50 & 50 & 38.06 & 41.61 & 39.2 & 39.62 & 19.23 \\
\hline 17 & $\begin{array}{l}\text { H2.0 - } \\
\text { P0G100 }\end{array}$ & 2.0 & 0 & 100 & 30.30 & 30.24 & 34.10 & 31.55 & -5.06 \\
\hline 18 & $\begin{array}{l}\mathrm{H} 2.0 \text { - } \\
\text { P100G0 }\end{array}$ & 2.0 & 100 & 0 & 30.6 & 30.24 & 34.47 & 31.77 & -4.39 \\
\hline 19 & $\begin{array}{l}\text { H2.0 - } \\
\text { P20G80 }\end{array}$ & 2.0 & 20 & 80 & 35.6 & 38.61 & 39.4 & 37.87 & 13.96 \\
\hline 20 & $\begin{array}{c}\mathrm{H} 2.0- \\
\text { P40G60 }\end{array}$ & 2.0 & 40 & 60 & 36.95 & 36.76 & 37.35 & 37.02 & 11.41 \\
\hline 21 & $\begin{array}{l}\mathrm{H} 2.0- \\
\text { P50G50 }\end{array}$ & 2.0 & 50 & 50 & 36.11 & 36.69 & 35.09 & 35.96 & 8.22 \\
\hline
\end{tabular}




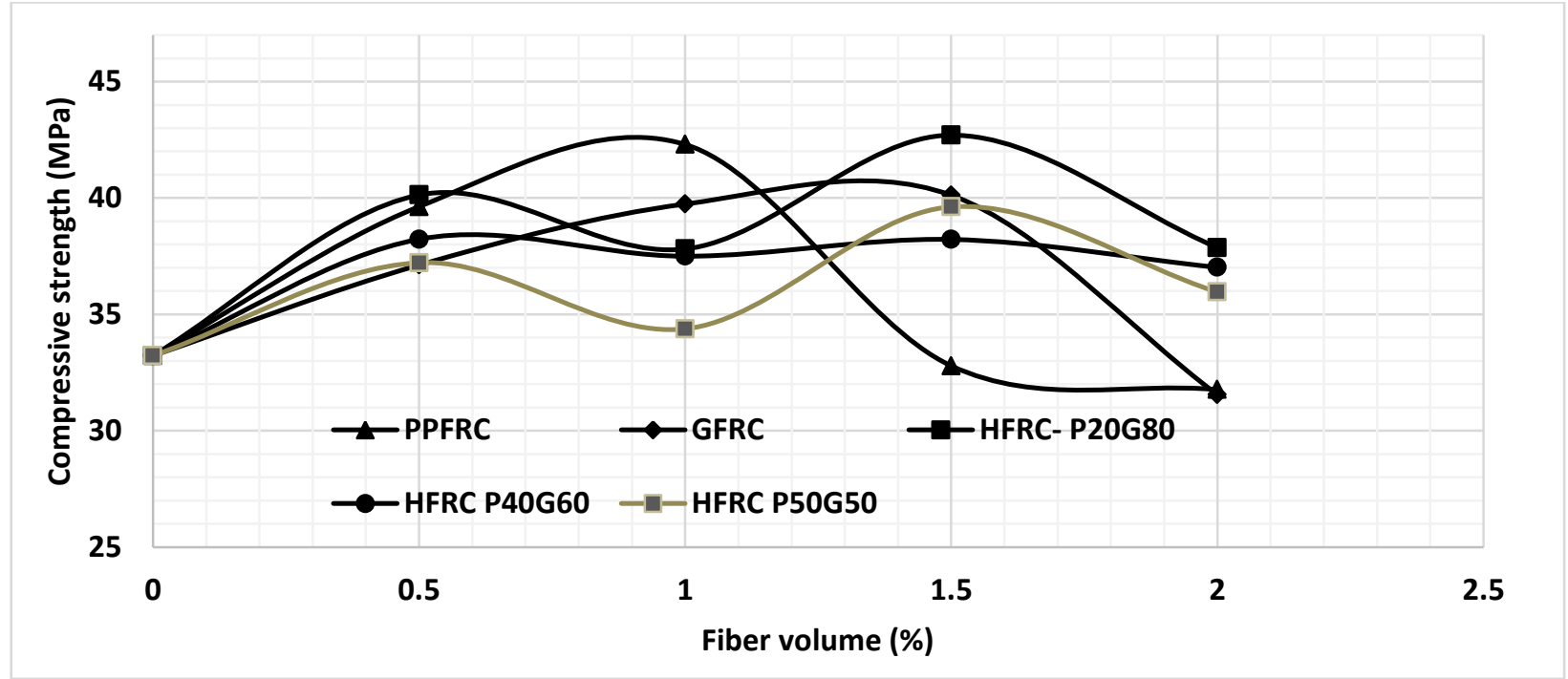

Figure 3: Variation of compressive Strength against fiber volume content

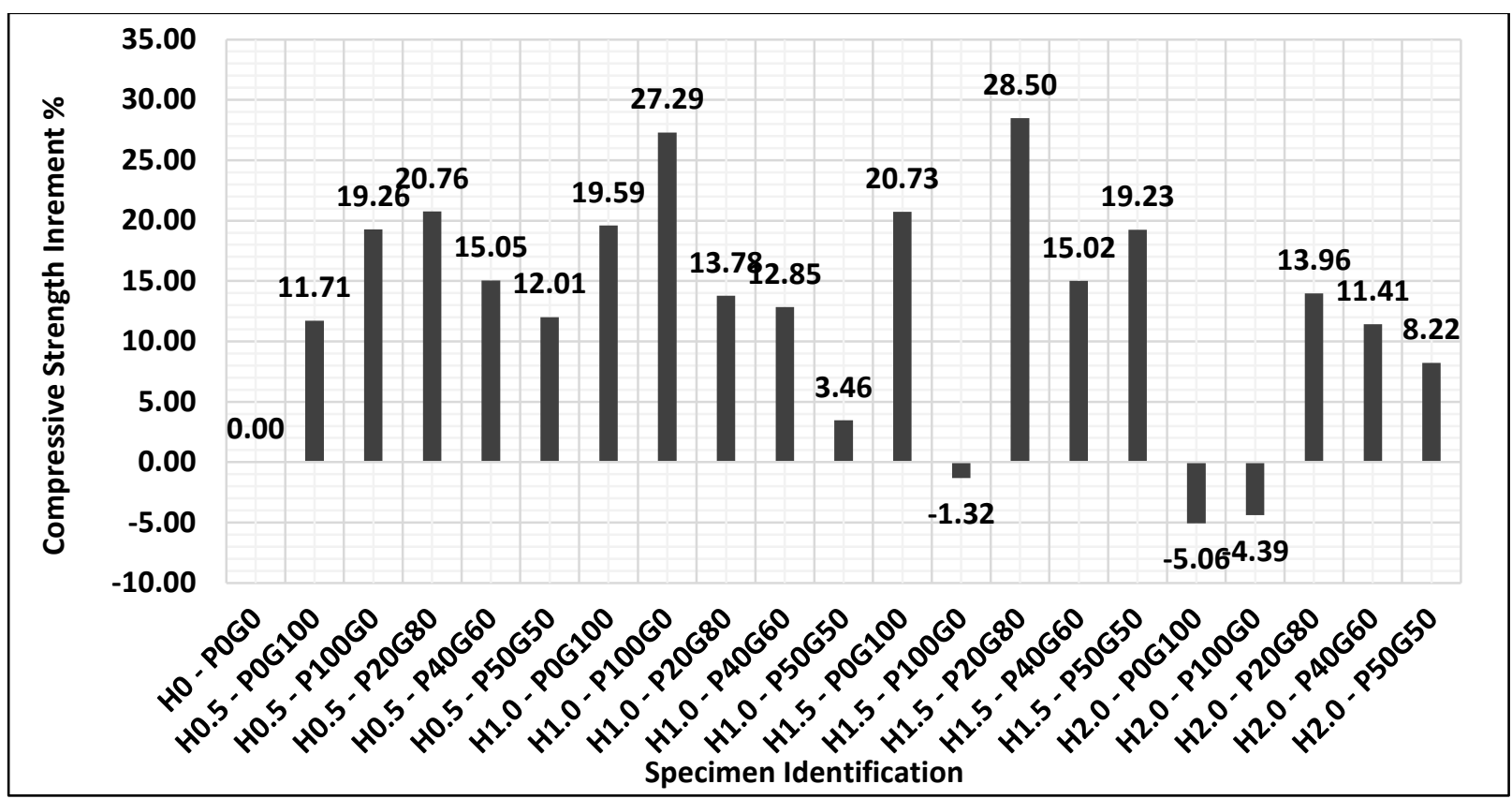

Figure 4: Variation of Compressive Strength Increment against fiber volume content

The hybrid fiber specimen H0.5P20G80, H0.5P40G60 and H0.5P50G50 gave compressive strength of $40.13 \mathrm{~N} / \mathrm{mm}^{2}, \quad 38.23 \mathrm{~N} / \mathrm{mm}^{2}$ and $37.22 \mathrm{~N} / \mathrm{mm}^{2}$ respectively giving an increment of $20.76 \%, 15.05 \%$ and $12.01 \%$ in strength. At the $0.5 \%$ of fibre addition, specimen H0.5P20G80 gave the maximum performance in strength.

Similarly, at $1.0 \%$ fibre volume, specimen H1.0P0G100 and H1.0P100G0 gave a compressive strength of $39.74 \mathrm{~N} / \mathrm{mm}^{2}$ and $42.3 \mathrm{~N} / \mathrm{mm}^{2}$ resulting in strength increment of $19.5 \%$ and $27.29 \%$.

The hybrid fibre specimens H1.0P20G80, H1.0P40G60 and H1.0P50G50 gave compressive strength of $37.81 \mathrm{~N} / \mathrm{mm}^{2}, \quad 37.5 \mathrm{~N} / \mathrm{mm}^{2}$ and $34.38 \mathrm{~N} / \mathrm{mm}^{2}$ respectively, showing increment of $13.78 \%, 12.85 \%$ and $3.46 \%$ in compressive strength compared with the control specimen. Specimen H1.0P100G0 gives the maximum compressive strength of $44.25 \mathrm{~N} / \mathrm{mm}^{2}$ at this fibre volume.

At $1.5 \%$ fibre volume, specimen H1.5P0G100 and H1.5P100G0 gave compressive strength of 40.12 $\mathrm{N} / \mathrm{mm}^{2}$ and $32.79 \mathrm{~N} / \mathrm{mm}^{2}$ corresponding to an increment of $20.75 \%$ and $-1.32 \%$ in compressive strength. Specimen H1.5P100G0 gave a compressive strength below the control specimen. From the hybrid fibre specimens H1.5P20G80, H1.5P40G60 and H1.5P50G50 compressive strength value of $42.7 \mathrm{~N} / \mathrm{mm}^{2}, \quad 38.33 \mathrm{~N} / \mathrm{mm}^{2}$ and $39.62 \mathrm{~N} / \mathrm{mm}^{2}$ respectively were obtained giving an increment in strength by $28.5 \%, 15.02 \%$ and $19.23 \%$ respectively. It 
was observed that specimen H1.5P20G80 had the maximum strength of $42.7 \mathrm{~N} / \mathrm{mm}^{2}$.

At $2.0 \%$ fibre volume, compressive strength of specimen H2.0P0G100 and H2.0P100G0 was $31.55 \mathrm{~N} / \mathrm{mm}^{2}$ and $31.77 \mathrm{~N} / \mathrm{mm}^{2}$ indicating a reduction in strength when compared with the control specimen. The strength reduction was $-5.06 \%$ and $-4.39 \%$ respectively. The hybrid specimen H2.0P20G80, H2.0P40G60 and H2.0P50G50 gave strength increment of $13.56 \%, 11.41 \%$ and 8.225 compared with the control specimen. Fibre up to a certain percentage reduces crack propagation and brittleness of concrete. Increase in compressive strength is because the presence of both fibres tend to bridge the micro cracks in the concrete the fibres in the concrete usually serve as bridges, which prevent further opening and development of cracks and prevent samples from complete failure, thus creating an increase in compressive strength. One other reason for increment in compressive strength up to a certain percentage of fibre is that introducing fibres against the other plane of concrete helps to reduce shear stress in concrete by taking up some of them out and hence they help increase the compressive strength. Decrease in compressive strength at higher fibre volumes is due to the fact that inclusion of fibres at higher volumes, if it is clustered will cause low workability and initial defect in concrete, resulting in reduction of compressive strength. This reduction is attributed to air voids, compaction and consolidation problems. Also, similar findings were reported by [20], in their report higher percentage of hybridization and higher amount of fibres produce higher porosity in the matrix and also interfers with the cohesiveness of the matrix, which leads to bailing effect resulting in decrease in compressive strength.

\subsection{Split Tensile Strength Test Result}

The experimental results obtained for split tensile strength test is presented in Table 3 and Figure 5. Split tensile strength is a measure of the ability of material to resist a force that tends to pull it apart. It is expressed as the minimum tensile stress needed to split the material apart. Twelve specimen's results were obtained for split tensile strength during the experiment. Results obtained from the experiment prove that the addition of fibres to concrete have positive effect on the split tensile strength of concrete At $0.5 \%$ fibre volume, though there was no significant improvement in split tensile strength, but the hybrid fibre specimens H0.5P20G80 and H0.5P40G60 have higher tensile strength than the control specimen and ARGF specimen H0.5P0G100. The tensile strength result shows significant increase in strength at $1.0 \%$ fiber volume. Specimen H1.0P0G100 and H1.0P100G0 have tensile strength values of $3.0 \mathrm{~N} / \mathrm{mm}^{2}$ and $2.91 \mathrm{~N} / \mathrm{mm}^{2}$ resulting in $32.75 \%$ and $28.74 \%$ tensile strength increment. The hybrid fibers H1.0P20G80 and $\mathrm{H} 1.0 \mathrm{P} 40 \mathrm{G} 60$ gave tensile strength of $2.94 \mathrm{~N} / \mathrm{mm}^{2}$ and $2.93 \mathrm{~N} / \mathrm{mm}^{2}$.

Table 3: Split Tensile strength test experimental result

Volume of individual fiber

S/No. Specimen Id $\quad$ Volume of HRF Polypropylene (\%) ARGF (\%) $\quad$ Split Force $\begin{gathered}\text { Tensile } \\ \begin{array}{c}\text { Strength } \\ \left(\mathrm{N} / \mathrm{mm}^{2}\right)\end{array}\end{gathered} \begin{gathered}\% \\ \text { Increase }\end{gathered}$

\begin{tabular}{rlrrrrll}
\hline 1 & H0 - P0G0 & 0 & 0 & 0 & 159.7 & 2.26 & Control \\
2 & H0.5-POG100 & 0.5 & 0 & 100 & 160.7 & 2.27 & 0.63 \\
3 & H0.5 - P20G80 & 0.5 & 20 & 80 & 163.7 & 2.32 & 2.50 \\
4 & H0.5 - P40G60 & 0.5 & 40 & 60 & 175.5 & 2.48 & 9.89 \\
5 & H1.0 - P0G100 & 1 & 0 & 100 & 212 & 3.00 & 32.75 \\
6 & H1.0 - P100G0 & 1 & 100 & 0 & 205.6 & 2.91 & 28.74 \\
7 & H1.0 - P20G80 & 1 & 20 & 80 & 207.5 & 2.94 & 29.93 \\
8 & H1.0 - P40G60 & 1 & 40 & 60 & 206.7 & 2.93 & 29.43 \\
9 & H1.5 - P20G80 & 1.5 & 20 & 80 & 165.2 & 2.34 & 3.44 \\
10 & H1.5 - P40G60 & 1.5 & 40 & 60 & 161.9 & 2.29 & 1.38 \\
11 & H2.0 - P20G80 & 2 & 20 & 80 & 175.9 & 2.49 & 10.14 \\
12 & H2.0 - P40G60 & 2 & 40 & 60 & 166.6 & 2.36 & 4.32 \\
\hline
\end{tabular}




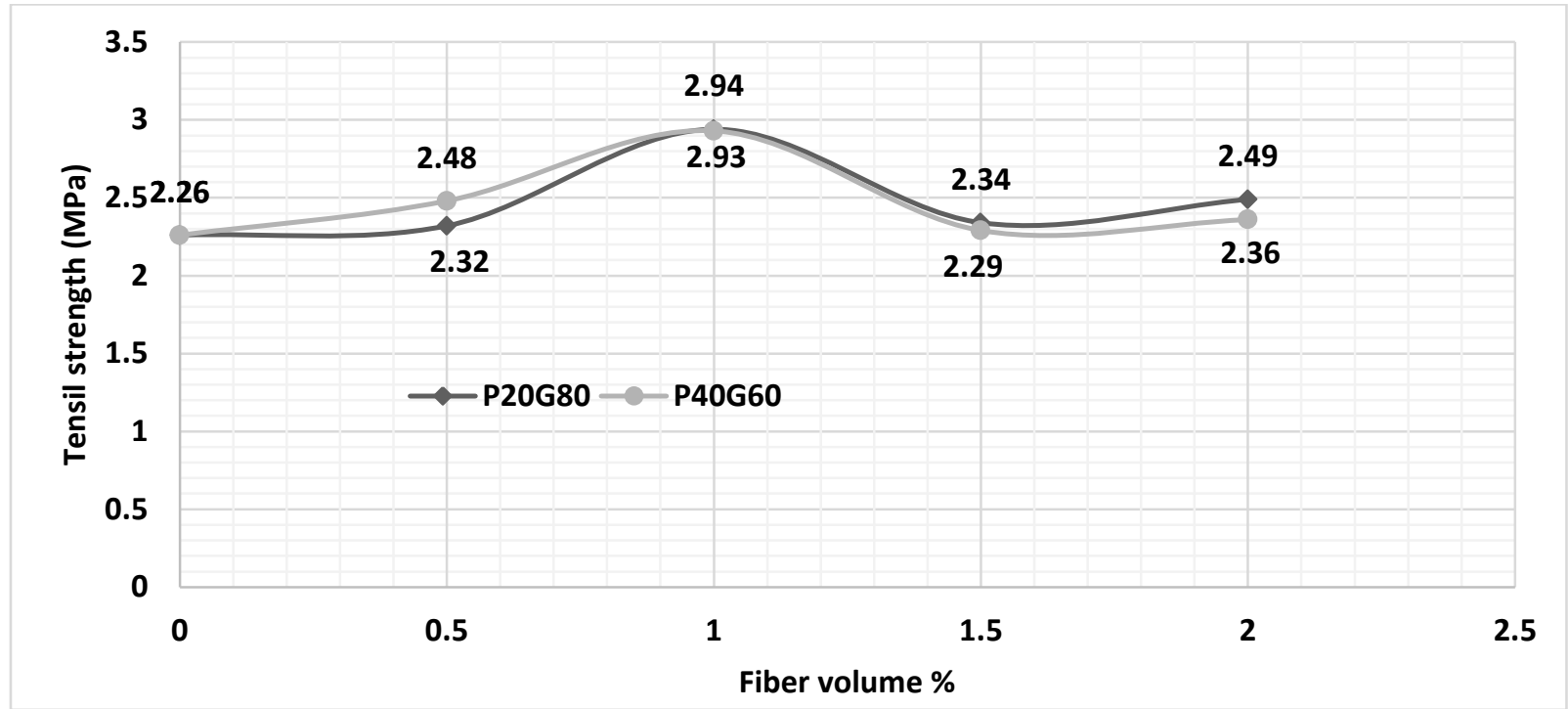

Figure 5: Variation of Split tensile Strength against fiber volume content

There was significant drop in tensile strength as the fibres volume increased above $1.0 \%$. The drop in tensile strength with higher fibre mass is as a result of the fact that higher mass of fibre promotes multiple cracks. It was observed that alkali resistant and polypropylene hybrid fibre reinforced concrete specimen attained maximum split tensile strength at fiber volume of $1.0 \%$, while specimen H0.5P0G100 gave the lowest split strength. The same reasons for increase in compressive strength by [21] are applicable for the increase in split tensile strength up to a certain percentage of fibre mass. It was also established by [21] that there was deficiency in the transition zone between the fibres and the concrete paste with a lot of porosity and hence the split tensile strength was reduced.

\subsection{Flexural Strength}

The flexural strength values for the tested beams are shown in Table 4 and plotted in Figure. 6. The flexural strength test result shows that the fibre combination of $40 \% \mathrm{PPF}$ and $60 \% \mathrm{ARGF}$ at fibre volume fraction of $1.0 \%$ attained $59.73 \%$ increment in flexural strength when compared with the control specimen. This was the highest value of flexural strength. The ultimate load attained at that fibre content was $18.05 \mathrm{kN}$. Specimen H2.0P40G60 gave the lowest flexural strength of $5.02 \mathrm{~N} / \mathrm{mm} 2$ at fibre volume fraction of $2.0 \%$ and had a flexural strength increment of $11.06 \%$.

At $0.5 \%$ fibre volume fraction, the hybrid fibre specimens H0.5P20G80 with flexural strength increment of $44.07 \%$ shows better performance than the control sample. ARGF specimen at the same fibre volume fractions gave strength increment of $33.27 \%$, with a flexural strength of $6.024 \mathrm{~N} / \mathrm{mm}^{2}$.

\begin{tabular}{llllll}
\hline $\begin{array}{l}\text { S/N } \\
\text { o. }\end{array}$ & $\begin{array}{l}\text { Specimen } \\
\text { Identification }\end{array}$ & $\begin{array}{l}\text { Yield Load } \\
(\mathrm{KN})\end{array}$ & $\begin{array}{l}\text { Ultimate Load } \\
(\mathrm{KN})\end{array}$ & $\begin{array}{l}\text { Flexural Strength } \\
\left(\mathrm{KN} / \mathrm{m}^{2}\right)\end{array}$ & $\begin{array}{l}\text { Flexural strength \% } \\
\text { increment }\end{array}$ \\
\hline 1 & H0 - P0G0 & 10.04 & 11.3 & 4.52 & 0.00 \\
2 & H0.5 - P0G100 & 11.3 & 15.06 & 6.024 & 33.27 \\
3 & H0.5 - P20G80 & 11.3 & 16.28 & 6.512 & 44.07 \\
4 & H0.5 - P40G60 & 11.3 & 15.06 & 6.024 & 33.27 \\
5 & H1.0 - P0G100 & 15.06 & 16.28 & 6.512 & 44.07 \\
6 & H1.0 - P100G0 & 15.06 & 15.06 & 6.024 & 33.27 \\
7 & H1.0 - P20G80 & 15.06 & 16.32 & 6.528 & 44.42 \\
8 & H1.0 - P40G60 & 16.32 & 18.05 & 7.22 & 59.73 \\
9 & H1.5 - P20G80 & 12.55 & 15.06 & 6.024 & 33.27 \\
10 & H1.5 - P40G60 & 12.55 & 15.06 & 6.024 & 33.27 \\
11 & H2.0 - P20G80 & 11.3 & 15.06 & 6.024 & 33.27 \\
12 & H2.0 - P40G60 & 11.3 & 12.55 & 5.02 & 11.06 \\
\hline
\end{tabular}




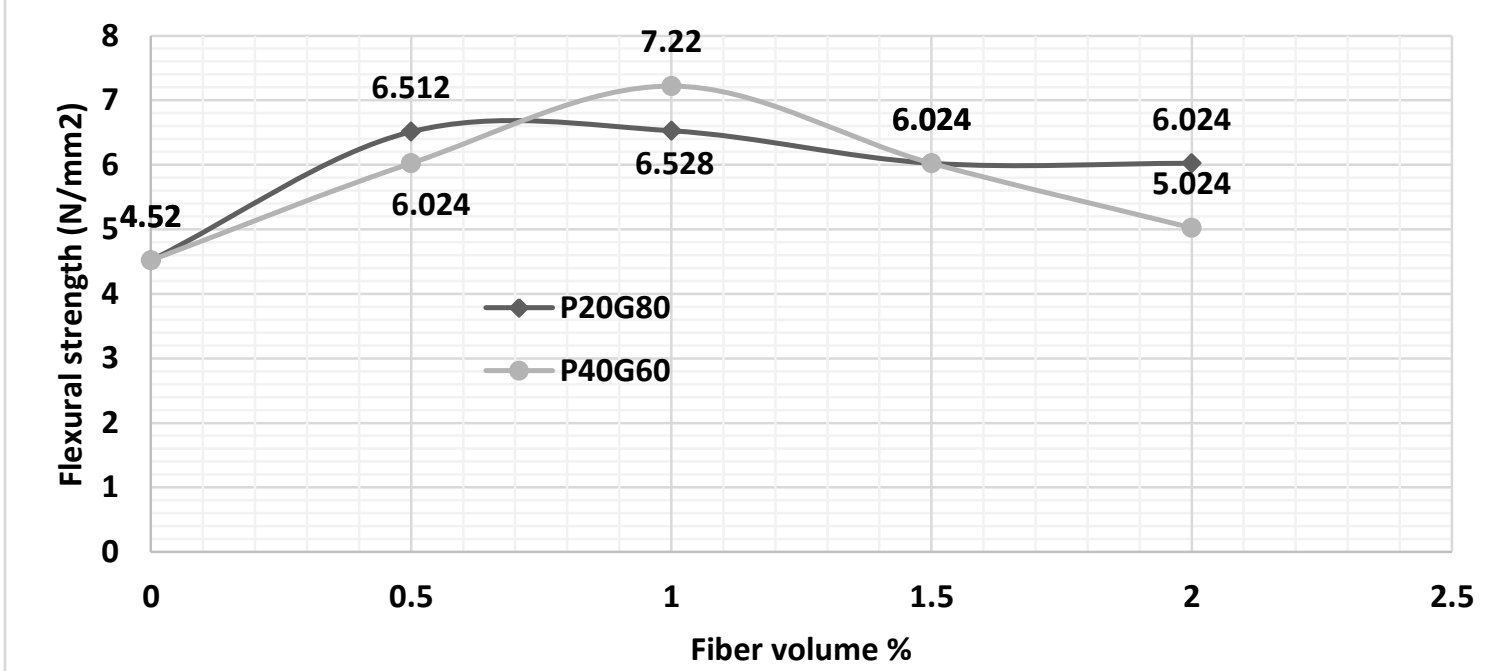

Figure 6: Variation of flexural Strength against fiber volume content

Specimen H0.5P0G100, H0.5P40G60, H1.0P100G0, H1.5P20G80, H1.5P40G60 and H2.0P20G80 attain the same flexural strength of $6.024 \mathrm{~N} / \mathrm{mm}^{2}$, with strength increment of $33.27 \%$ compared to the control sample. It was observed that specimen H1.0P40G60 had the highest flexural strength with a value of $7.22 \mathrm{~N} / \mathrm{mm}^{2}$.

The reason for the strength development is the same for the split tensile strength

\subsection{Strength Prediction Model}

The coefficients of linear equation involving more than one independent variable can be obtained using multiple linear regression analysis. The mathematical model used for predicting the strength of hybrid fibre is expressed by linear equation of the form:

$$
f_{H}=f_{0}+b_{1 \times 1}+b_{2 \times 2}+\cdots+b_{n \times n}
$$

Where, $\mathrm{f}_{\mathrm{H}}$ is the predicted strength, $\mathrm{f}_{0}$ the dependent variable is the experimental strength, $b_{1}, b_{2} \ldots . . b n$ are regression coefficients and $x_{1}, x_{2} \ldots . . x_{n}$ are the independent variables.

The strength result obtained from the specimens where analyzed with the aid of a computer using Microsoft excel to obtain regression equations. The equations obtained from multiple regression analysis are given as: Compressive strength:

$$
C=33.23-2.1104 X+0.0609 Y+0.0765 Z
$$

Split tensile strength:

$$
T=2.26-0.089 \mathrm{X}+0.0061 \mathrm{Y}+0.0033 \mathrm{Z}
$$

Flexural strength:

$$
F=4.52-0.4741 X+0.0203 Y-0.0227 Z
$$

Where $\mathrm{C}, \mathrm{T}$ and $\mathrm{F}$ are the predicted compressive strength, split tensile strength and flexural strength respectively, $\mathrm{X}$ is the volume of hybrid fibre, $\mathrm{Y}$ is the volume of polypropylene fibre and $\mathrm{Z}$ is the volume of alkali resistance glass fibre in the concrete mix.

The model regression equations derived were used to predict the strength of hybrid fiber reinforced concrete as shown in Tables 5 and 6 . The values were compared with the compressive strength of the experimental specimens.

For compressive strength, split tensile strength and flexural strength, the deviations between the experimental and predicted values were $-12.41 \%$ to $16.19 \%,-13.03 \%$ to $12.16 \%$ and -13.86 to $14.45 \%$ respectively.

\section{CONCLUSION}

Based on the results obtained from experimental investigations presented in this study, the following conclusions where derived.

[1] The regression equation for strength prediction, estimated the strength parameters close to the experimental values.

[2] Alkali resistant glass - polypropylene hybrid fibre reinforced concrete specimen attain maximum compressive strength of $42.7 \mathrm{~N} / \mathrm{mm}^{2}$ at fibre volume of $1.5 \%$ with $\mathrm{r}$ atio of $80 \%$ ARGF and $20 \%$ PPF.

[3] At 2.0\% fiber volume fraction, there was a significant drop in compressive strength of ARGF and PPF reinforced concrete specimens, while the hybrid fibre reinforced concrete specimens show significant increase in compressive strength.

[4] At $0.5 \%$ and $1.0 \%$ fibre volume ratio, polypropylene fibre reinforced concrete specimens because of it lower fibre aspect ratio tends to have higher increment in compressive 
strength than alkali resistant glass fibre reinforced concrete specimens with higher aspect ratio.

[5] Split tensile increases with the addition of fibres. Maximum split tensile strength for the hybrid fibre reinforced concrete specimens was $2.94 \mathrm{~N} / \mathrm{mm}^{2}$ attained at $1.0 \%$ fibre volume and fibre ratio of $80 \%$ ARGF and $20 \%$ PPF.

[6] The ultimate flexural strength attained for the hybrid fibre reinforced concrete specimens was $7.22 \mathrm{~N} / \mathrm{mm}^{2}$, with strength increment of $59.75 \%$ at $1.0 \%$ fibre volume and fibre ratio of $60 \%$ ARGF and $40 \%$ PPF.

\section{REFERENCES}

[1] American Concrete Institute ACI 544.IR-96 "State of art Report on fiber Reinforced Concrete" Reported by ACI Committee 5442002.

[2] American Concrete Institute "Measurement of properties of Fiber Reinforced Concrete" ACI 544.2R-89 1996.

[3] Komal, C. and Bharti, T.. Studies of Glass Fiber Reinforced Concrete Composites. International Journal of Structural and Civil Engineering Research. ISSN 2319-6009, Vol.2, No. 3, pp 176 182, 2013.

[4] Janardhan, G. and Sri Chandana, P. Performance Assessment of Glass Fiber M Reinforced Concrete Beams. International Journal and Magazine of Engineering, Technology, Management and Research, Volume 2, Issue 10, 2015.

[5] Mahendra, P., Chandak, R. and Grover, R. Comparative Study of Propylene Fiber Reinforced Silica Fume Concrete With Plain Cement Concrete International Journal of Engineering Research And Science And Technology. Vol. 2. No.4. 2013

[6] Sravana, P., Srinivasa, P. R, and Seshadri, T. S. Flexural behavior of glass fiber reinforced selfcompacting concrete slab. 35th Conference on our World in concrete and structures: 25-27 August 2010, Singapore, 2010.

[7] Madhari T, Swamy, L, and Deepak M. Polypropylene fiber reinforced concrete" International Journal of Emerging Technology and Advanced Engineering Vol.4, pp 114-119, 2014.

[8] Krishnamurthy, B' S., Balamuralikrishman, R. and Shakil, M.. An Experimental Work on Alkaline Resistance Glass Fiber Reinforced Concrete. International Journal of Advanced Engineering Management and Science Vol. 3, Issue 7, ISSN: 2454-1311, pp 730-737, 2017.

[9] Mohankar, R. H., Pidurkar, M. D., and Thakre, P. V..
Hybrid Fiber reinforced Concrete. Internationalal Journal of Science, Engineering and Technology Research. Volume 5, Issue 1, 2016.

[10] Saman, K., Roohul, A. K., Amadur, R. K. and Misbahul, I. Mechanical properties of Polypropylene Fibre reinforced Concrete for M 25 \& M 30 mixes: A Comparative study. International Journal of Scientific Engineering and Applied Science- Volume-1, Issue-6, 2015.

[11] Murahari, K. and Rama Mohan, R.. Effects of polypropylene fibers on the strength properties of fly ash based concrete. International Journal of Engineering Science Invention, Volume 2 Issue 5. pp13-19, 2013.

[12] Chaitanya, J. D. and Arunakanthi, E. Experimental Studies of Fiber Reinforced Concrete International Journal Of Civil Engineering And Technology (IJIET), Vol. 7, 2016.

[13] British Standards 196.1: Methods of Testing Cement. British Standards Institute. London, United Kingdom, 2016.

[14] British Standards 812-103.1. Methods for Testing Fine Aggregate. British Standards Institute. London, United Kingdom, 1985.

[15] British Standards 812-103.2. Methods for Testing Coarse Aggregate. British Standards Institute. London, United Kingdom, 1989.

[16] British Standard 3148. Methods of test for Water for making concrete. British Standards Institute. London, United Kingdom, 1980.

[17] British Standard 1881-116 Testing ConcreteMethod for Determination of Compressive Strength of Concrete Cubes. British Standards Institute. London, United Kingdom, 1983.

[18] British Standard 1881; Part 117. Testing Concrete-Method for Determination of Tensile Splitting Strength. British Standards Institute. London, United Kingdom, 1983.

[19] British Standard 1881, Part 118. Testing Concrete-Method for Determination of Flexural Strength. British Standards Institute, London, United Kingdom, 1983.

[20] Saman, K., Roohul, A. K., Amadur, R. K. and Misbahul, I. Mechanical properties of polypropylene fibre reinforced concrete for M25 and M30 mixes.: A comparative study.. International Journal of Scientific Engineering and Applied Science, Vol. 1, No. 6, 2015.

[21] Kanagavel, R. and Kalidass, A.. Mechanical properties of hybrid fibre reinforced quaternary concrete. Journal of the Croatioan Association of Civil Engineers. Vol. 69, No.1 pp 1-10, 2017. 